\title{
Emerging Trends and the General Framework for the Exercise of Sentencing Discretion in Botswana
}

\author{
Ikanyeng S. Malila* \\ Faculty of Social Sciences, University of Botswana, Gaborone, Botswana
}

\begin{abstract}
Like other common law jurisdictions, Botswana has, in recent years, seen an increase in the number of interventions by the legislature to structure sentencing powers of judges through primary legislation. This trend has given rise to concerns about the erosion of the sentencing discretion of judges in some quarters. Against this background the present paper outlines and discusses the nature of discretion exercisable by judges in sentencing matters in Botswana and the general framework for the exercise of such powers. The paper argues that despite the recent increase in the volume of mandatory minimum enactments, the general framework for the exercise of discretion in Botswana remains fundamentally unchanged not least because the courts have in some measure reclaimed some of the discretion they had lost as a result of unprecedented expansion in the volume of mandatory minimum legislation in the 199os. More positively, a recent amendment to the Penal Code restoring some of the judges' discretion suggests that parliament has come to recognise the need for and importance of greater flexibility in the structure of the sentencing discretion of judges.
\end{abstract}

Keywords

sentencing discretion; mandatory minimum legislation; punishment

\section{Introduction}

The past two decades have been marked by two developments of unparalleled significance in the history of judicial discretion in Botswana. First, there has been an unprecedented increase in the volume of mandatory minimum enactments promulgated by the legislature. ${ }^{1}$ Second, and similarly unprecedented, has been the regularity with which the Court of Appeal has found it necessary to strike down certain provisions of such mandatory minimum enactments which it deemed constrained the discretion of judges in relation to sentencing, as being in conflict with

*) Dr. Malila is a lecturer in the Faculty of Social Sciences, University of Botswana. He teaches mainly on Criminology and Criminal Justice Studies programme. E-mail: malila@mopipi.ub.bw.

1) These include the following: Penal Code (Amendment) Act no 13 of 1993, Sections 2 and 3; Drugs and Related Substances Act, no. 18 of 1992, Section 16; Road traffic (Amendment) Act 18 of 1993, Motor Vehicle Theft Act, no. 17 of 1995 Section 3; Stock Theft Act, no. 21 of 1996, Section 3 and Penal Code (Amendment) Act, no. 5 of 1998, Sections 3,4 and 8 . 
the Constitution. ${ }^{2}$ Between 1990 and 2000 parliament passed no less than eight enactments which carried mandatory minimum penalties ${ }^{3}$ thereby increasing by almost twofold the number of such pieces of legislation on the statute books. ${ }^{4}$ In the decade that followed, the Court of Appeal struck down provisions in most of these statutes that restricted the powers of judges to decide whether to order sentences to run consecutively or concurrently as provided for in Section 300(2) of the Criminal Procedure and Evidence Act. ${ }^{5}$ Such provisions compel the trial courts to impose penalties that often result in heavy aggregate sentences, which on appeal, have been overturned as unconstitutional by the Court of Appeal. While the shift towards mandatory minimum laws appears at first glance to have been no more than a local response to the problem of escalating crime,${ }^{6}$ and public demand for countermeasures, ${ }^{7}$ it was in fact not a unique development peculiar to the country. 8

Legislatures in the common law world, including Botswana, appear increasingly to regard structuring sentencing discretion as the most immediate and effective way of changing sentencing patterns, sentencing practices, and more broadly sentencing policy. ${ }^{9}$ A notable pattern/trend over the past three decades or so has been that legislative enactments in different jurisdictions that have had a bearing on sentencing discretion have tended to be designed mostly to restrict rather than extend judicial discretion.

Alteration or re-adjustment of judicial discretion may be done in pursuit of a variety objectives ranging from overtly political goals ${ }^{10}$ to those supposedly strictly concerned with sentencing principles. From the narrow perspective of sentencing, restriction of the sentencing discretion of judges is usually done with the aim of, amongst other things, increasing consistency in sentencing, reducing or increasing severity of sentences for particular offences, reducing or extending the menu of possible disposals, and increasingly, in many jurisdictions, to achieve a deterrent effect in respect of a particular offence or offences. Quite often one or more of

\footnotetext{
2) See, e.g., Thabiwa and another v the State (2003) 2B.L.R. 39 (CA); Moatshe v State: Motshwari and another (2004) 1B.L.R. 1 (CA); Ramaphoiv State (2007) 1B.L.R. 697 (HC) and Matlho v State (2008) 1B.L.R. 84 (CA).

3) Supra, note 1 .

4) See D.D.N. Nsereko, 'Minimum Sentences and Their Effects on Judicial Discretion', $3_{1}$ Crime and Social Change (1999), 363-384.

5) Criminal Procedure and Evidence Act.

6) See Nsereko supra (note 4), 368.

7) See, e.g., 'A Report on the Proceedings of the National Workshop on Violence Against Women: Rape and Femicide in Botswana' (3-4 March 1995) - Workshop organized by Emang Basadi, The NGO Network on Women's Rights and WilDAF.

8) See http://www.justice.gc.ca/eng/pi/rs/rep-rap/2005/rro5.../p2.html (accessed 21 January 2012).

9) See generally Ibid.; M. Tonry, Sentencing Matters (Oxford University Press, Oxford, 1996); A. Ashworth Sentencing and Criminal Justice (London, Butterworth, 1992).

10) Tonry (Ibid.); M. Cavadino and J. Dignan, The Penal System, 3rd edn (London, Sage Publications, 2003), p. 105 .
} 
these objectives is given primacy perhaps with only secondary importance given to the others, if applicable.

As observed earlier, the trend in most countries is more towards restriction of judicial discretion and up scaling of punishments than expansion of discretion or liberalisation of punishment. ${ }^{11}$ This trend, which represents the most important paradigm shift to have occurred in recent times in respect of sentencing matters generally, and judicial discretion in particular, began to take root in advanced English-speaking countries from the 1970 os $^{12}$ In the developed world, the readiness of legislators regularly to intervene to reshape sentencing policy and to restrict the sentencing powers of judges in recent decades contrasts sharply with the legislative abstention for much of the 2oth century. ${ }^{13}$ Legislative abstention is believed by some to have led to the attitude among the judiciary that sentencing policy is the province of judges rather than the legislature. ${ }^{14}$

In Botswana, the proliferation of mandatory minimum legislation in past two decades, particularly the 1990s, has raised concern amongst legal scholars. ${ }^{15}$ Not surprisingly, the inequities occasioned by such legislation have generated a lot of appeals that have increasingly occupied the courts' time in recent times. Concerns regarding mandatory minimum enactments have focused not only on the erosion of the sentencing discretion of judges, ${ }^{16}$ but also on the efficacy of such legislation as a tool for fighting crime. ${ }^{17}$ Yet, outside the courtroom, there has been relatively little debate beyond scholarly circles concerning the subject of judicial discretion and less still that of sentencing discretion. What little public debate there has been around discretion has been surprisingly muted even though much of the new legislation was a product of lobbying by interest groups. ${ }^{18}$ Thus, unlike

11) It should be noted here that there are discernable differences in the patterns of punishment between developed and developing countries in that, in the former, both trends are evident. Frase refers to the phenomenon of bifurcation of sentences in the West characterised by 'increasing low-end leniency and high-end severity' (see R.S. Frase 'Comparative Perspectives on Sentencing Policy and Research' in M. Tonry and R.S. Frase (eds.), Sentencing and Sanctions in Western Countries (Oxford University Press, Oxford, 2001), p. 263). For discussion of trends in Africa and Botswana, see R.E.S. Tanner, 'Penal Practice in Africa - Some Restrictions on the Possibility of Reform', 10 The Journal of Modern African Studies (1972), 447-458; S. Coldham, 'Criminal Justice Policies in Commonwealth Africa: Trends and Prospects', 44 Journal of African Law (200o), 218-238; C. Love, 'Court Sentencing in Botswana: a Role for Probation?', 7 Journal of Social Development in Africa (2000), 5-17.

12) Tonry, Sentencing Matters, supra (note 9), 8.

13) See A. Ashworth, 'Sentencing Reform Structures', 16 Crime and Justice: A Review of Research (1992) $181-241$, at 198 .

14) Ibid., 198.

15) Nsereko supra (note 4); K. Frimpong 'The Role of the Criminal Justice System and Its Impact on Crime Prevention in Botswana' in K. Frimpong (ed.), Report on the Proceedings of National Conference on the Evaluation of Crime Prevention Programmes (6-8 September 2006).

16) For purposes of this paper, judge refers to any officer charged with presiding over a competent court.

17) Nsereko supra (note 4), 370-371.

18) For instance, the rape law was completely overhauled following heavy lobbying by a coalition of women's non-governmental organizations. See, for example, A Report on the Proceedings of the National Workshop on Violence Against Women: Rape and Femicide in Botswana (3-4 March 1995). 
in developed countries where sentencing discretion is widely debated in national newspapers, academic and public forums, especially parliament, in Botswana it is hardly ever given serious coverage or treatment. It has rarely featured as a subject of serious debate in the national legislature. Whenever it has been discussed in National Assembly, the debate has been cursory and has not tended to provoke further or broader debate outside parliament itself as might have been expected. It has been discussed more extensively in the House of Chiefs, but then only as part of a broader debate about chiefs' ${ }^{19}$ loss of power. ${ }^{20}$

The present paper considers the nature of sentencing discretion in Botswana in light of recent trends, and discusses and reviews the general framework for its exercise. In the concluding sections, the paper considers whether, on balance, there has been significant erosion of judges' sentencing discretion in Botswana especially taking into account recent attempts by the courts to reclaim some of the discretion they had lost and a corresponding magnanimous move by parliament to restore some of it.

\section{General Background and Context: A Note on Botswana's Dual Legal System}

One of the notable features of the Botswana's legal system is its dual in nature. ${ }^{21}$ This refers two an arrangement whereby customary courts and western-style courts, also known as general courts, exist side by side as do customary law and general law. Even so, relative to one another, the structure of customary and general courts can perhaps be more accurately described as a semi-parallel in that the latter exercise both appellate and supervisory functions over the former. The general legal system is in all important respects the dominant system. ${ }^{22}$ It is worth noting that in relation to criminal matters the system as a whole is characterised by duality of courts without duality of law because customary and general courts, have since 1972 when criminal law was universalised, been applying the same basic law based mainly on the Penal Code. ${ }^{23}$

19) Chiefs and Headmen serve as judges in customary courts.

20) See House of Chiefs Debate on the Customary Courts (Amendment) Bill, 2001. See more generally J.H. Proctor, 'The House of Chiefs and the Political Development of Botswana', 6 Journal of Modern African Studies (1968). 59-79; S.A. Roberts, 'The Survival of Traditional Tswana Courts in the National Legal System of Botswana', 16 Journal of African Law (1972), 103-129; and B. Otlhogile, 'Criminal Justice and the Problems of Dual Legal System in Botswana', 4 Criminal Law Forum (1993), 521-533.

21) See generally Otlhogile Ibid., A.J.G.M. Sanders, 'Legal Dualism in Lesotho, Botswana and Swaziland: A General Survey', 1 Lesotho Law Journal (1985) 47-67; C.M. Fombad 'Customary Courts and Traditional Justice in Botswana: Present Challenges and Future Perspectives', 1 Stellenbosch Law Review (2004), 165-196.

22) See Customary Courts Act Section 2(1).

23) The High Court confirmed in State vs Molomo 1984 B.L.R 108(HC) that a customary court has jurisdiction to try an offence if it is an offence created by 'the Penal Code or some other enactment and was not an offence listed in Section 12 of the Customary Court Act.' In Molomo's case the issue was whether a customary court had power to try an offence under the Fauna Conservation Act. 
Following a transitional period (1964-1972) in which customary courts continued to apply customary criminal law while ordinary courts applied the Penal code, it was considered that it was necessary to bring punishments in the two systems more into line with each other. To that end the Customary Courts (Act) was amended in 1971. The Amendment Bill of 1971 was primarily intended, according to the memorandum to the bill 'to limit the offences for which a customary court may impose a sentence of corporal punishment.'24 This would have the effect of bringing punishments customary courts could impose more in line with the Penal Code. ${ }^{25}$ These re-alignments made it possible for all the recognised courts to begin to operate according to broadly similar principles and within the overall framework of the Constitution.

Nevertheless, the 1971 reforms made allowances for some degree of flexibility in the way customary courts could exercise their power to punish offenders. The intention behind this was presumably to enable customary courts to continue to follow, in a limited way, their own patterns of punishing wrongdoing. As we shall see later, statutes governing customary, and the Penal Code ${ }^{26}$ which governs punishment in the general courts, carry different types of restrictions regarding choice of and substitutability of punishment. This has, for a long time, been an important difference in the discretion of officers presiding over the lower courts. It is also probably a significant source of differences in the punishment patterns of general and customary courts.

Notwithstanding the foregoing, while the general courts may not impose their way of doing things on customary courts, they still define the broad normative parameters within which the latter must operate, ${ }^{27}$ including in sentencing matters. Thus even as customary courts are presumed to follow their own patterns; their decisions are subject to appeal and they remain under supervisory review of the general courts, amongst other structures. Like subordinate general courts or magistrate courts, customary courts are, where appropriate, bound by and therefore expected to follow decisions of the higher courts. However, it is doubtful whether this actually translates into normative practice, because the transmission of principles that may be articulated in guideline and other judgments issued by the higher courts to customary courts is hampered by, among other things, limited of access to jurisprudence of higher courts ${ }^{28}$ and the low literacy levels

\footnotetext{
24) Memorandum of the Customary Courts (Amendment) Bill (1971) G299.

25) I.G. Brewer, 'A Note on the Botswana Customary Courts (Amendment) Act 1972', 6 Comparative International Law Journal of Southern Africa (1973), 282-286.

26) Customary Courts Act Sections 18-27.

27) See, e.g., State $v$ Thokomelo and Others (1981) B.L.R 272 (HC).

28) Customary courts are advised of important decisions that affect them through administrative circulars.
} 
of court personnel in these courts. ${ }^{29}$ In addition customary courts, ${ }^{30}$ including the Customary Court of Appeal ${ }^{31}$ seem to have a cavalier, and even hostile attitude towards mandatory formal procedure rules. This is not entirely surprising given that mandatory written rules were introduced fairly recently to customary courts. Furthermore, traditional leaders feel that their powers have been usurped by modern institutions of the state. ${ }^{32}$

\section{General Framework for the Exercise of Sentencing Discretion}

\subsection{Sentencing Discretion: Nature and Scope}

As is generally the case in common law countries, the discretionary powers of judges in Botswana in sentencing matters cover a wide spectrum of issues and dimensions. In general terms, judges may be said to have discretion in relation to the following: (1) choice of disposal or punishment; (2) quantum of punishment that may be suffered by the offender; and (3) the aim(s) of the sentence in respect of a particular offence, class of offences, or type of offender(s). Apart from these, the discretion of individual judges or presiding officers may vary by jurisdiction (substantive or territorial) or by rank of the officer concerned or by type of court as the case may be. The present paper is not, in the main, concerned with latter forms of discretion.

\subsubsection{Choice of Punishment}

Choice of punishment is regulated by offence-creating statutes, general punishment section of the Penal Code, ${ }^{33}$ procedural ${ }^{34}$ and system-specific or courtspecific legislation such as the Customary Courts Act, ${ }^{35}$ and as such may vary according to the type of court. Even after the 1972 reforms alluded to above, customary courts have not been required to follow the standard menu of punishments found in the offence-creating sections of the Penal Code or its general punishment section ${ }^{36}$ or other statutes as far as choice of and substitutability of punishments is concerned providing the prescribed punishment is not a mandatory minimum penalty. ${ }^{37} \mathrm{~A}$ court of competent jurisdiction may impose any of the following punishments where such are prescribed in the relevant provisions of the

\footnotetext{
29) D.G. Boko, 'Fair Trial and Customary Courts in Botswana: the Question Legal Representation', 11 Criminal Law Forum (2000), 445-46o.

30) See, e.g., Dipheko $v$ The State (2007) 2B.L.R 371(HC).

31) See, e.g., Ntwayame v State (2008) 1B.L.R 167 (CA).

32) See J.H. Proctor, supra note 20.

33) Penal Code, Section 33.

34) Criminal Procedure and Evidence Act, part xvii.

35) Customary Courts Act, Section 18.

36) Penal Code, Section 33.

37) Customary Courts Act, Section 18(3)(a).
} 
offence-creating statute: ${ }^{38}$ death, ${ }^{39}$ imprisonment, corporal punishment, a fine, forfeiture, security to keep the peace and to be of good behaviour or come up for judgement or any other punishment provided by the Penal Code or by any other law. The last category presumably includes extramural labour and a discharge without punishment.

Before the Penal Code was amended in 2004, the menu of punishments restricted substitutability of punishments, and therefore the flexibility of the courts, considerably. In the case of general courts, where a mandatory maximum sentence ${ }^{40}$ was applicable they could replace the prescribed penalty with another punishment where substitution was allowed or suspend the sentence partially or wholly upon certain conditions, ${ }^{41}$ discharge the offender with a caution or reprimand. ${ }^{42}$ The 2004 amendment to the Penal Code was made in order to, amongst other things, ${ }^{43}$ (1) allow the use of corporal punishment (subject to certain restrictions based on the offender's age or gender) in respect of those offences punishable by imprisonment (except those listed under the Second Schedule of the Criminal Procedure and Evidence Act), in addition to or as a substitution for imprisonment; (2) allow the use of corporal punishment as an alternative to imprisonment in cases where the convicted person has defaulted from the payment of a fine. Thus choice as to punishment was extended by increasing substitutability of penalties.

The menu of punishment applicable to offenders who appear before customary courts, though based on broadly similar choices as those in Pre-2004 menu, has traditionally worked somewhat differently. A customary court may sentence a person who has been convicted to a fine, imprisonment, corporal punishment or a combination of these, providing it does not, amongst other things, exceed its jurisdiction in respect of any of these penalties or run afoul of certain stipulated restrictions ${ }^{44}$ A customary court may also bind a convicted person to keep the peace. ${ }^{45}$ The court may, where a charge has been proved, and having regard to certain factors, discharge the accused without proceeding to conviction if it thinks that it is 'inexpedient to inflict any punishment. ${ }^{146}$ Customary courts also have the power to suspend the sentence partially or wholly upon certain conditions, ${ }^{47}$ release offender with a caution or upon some other condition. As already noted,

\footnotetext{
38) Penal Code, Section 25.

39) Only the High Court may impose a death penalty in respect of appropriate specified offences.

40) Imprisonment was and remains the standard prescribed punishment for virtually all offences including minor ones even though in practice the courts tend substitute it for lesser other penalties. Incidentally Botswana has the second highest rate of imprisonment in Africa, see http://www.prisonstudies.org/.../ 40-world-prison-population-list. See also C. Love, supra note 11.

41) Criminal Procedure and Evidence Act, Section 308.

42) Ibid., Section 314.

43) Government Gazette Extraordinary vol. XLII, No. 53 (14 July 2004), B.49.

44) Customary Court Act, Section 18(1).

45) Ibid., Section 19(1).

46) Ibid., Section $20(1)$

47) Ibid., Section 24.
} 
customary courts are not bound to impose sentences that are prescribed in the offence-creating sections of the Penal Code and other laws except where they are otherwise required to do so. So the punishment or mixture of punishments that a customary court may impose in any particular instance is a matter entirely at the discretion of the court.

\subsubsection{Quantum of Punishment}

There are a number of general formulations found in the offence-creating sections and general punishments sections of the Penal Code and other statutes that provide the necessary guidance as to the nature and extent of discretion exercisable by a court as regards punishment in respect of particular offences.

The most generous of these formulations merely set the maximum penalties under the various options available to the court and leave the rest to the discretion of the judge. Most offences in the Penal Code fall under formulations of this type which are generally known as mandatory maximums. If the phrase used in the relevant offence-creating statute section applicable to an offence is that the offender "shall be liable" to such and such punishment or to punishment not exceeding such and such, then the court is in those circumstances, free not to punish altogether ${ }^{48}$ or if it decides to impose the prescribed punishment, it is free to fix the quantum as long as it does not exceed the maximum. ${ }^{49}$ As the judge in State $v$ Dlodlo ${ }^{50}$ put it, 'the word "shall be liable" imports an element of discretion.' It does not perforce mean that the convicted person will suffer the said punishment. Thus the courts wield considerable powers regarding disposal, even where conviction is all but certain, in that they have the discretion to discharge a defendant without proceeding to conviction where they consider that it may not be expedient to do so. ${ }^{51}$ However, in practice these powers are, perhaps understandably, used sparingly. ${ }^{52}$

If the phrase used in the statute is that the offender 'shall suffer or shall be sentenced to a prescribed punishment' then the sentence prescribed is mandatory and the court may not impose any other sentence apart from the prescribed sentence. ${ }^{53}$ This formulation is used in those statutes where a mandatory minimum sentence is prescribed. Mandatory minimum enactments sometimes provide fairly detailed statutory guidance regarding whether any other sentence that the court may wish to impose on the offender for any other charge for which the offender is being sentenced contemporaneously should run consecutively to or

\footnotetext{
48) Penal Code, Section $32(1)$.

49) See generally State v Dlodlo 1988 BLR 419 (HC).

50) Ibid.

51) Penal Code, Section 32(1); Customary Courts Act, Section 20.

52) See, e.g., Collins v The State (1971) BLR 15(HC) and State v Regoeng (1987) BLR476 (HC).

53) K.E. Obeng, The Law Relating to Arrests and Prosecution of Offenders in Botswana, 1st edn (K.E. Obeng, Gaborone, 1999), p. 283.
} 
concurrently with that imposed for the offence under consideration. The courts have shown, in a series of cases going back almost a decade, that such highly prescriptive legislation tends to constrain judges from exercising discretion as they could and should otherwise do in terms of section $300(2)$ of the Crime Procedure and Evidence Act. ${ }^{54}$ In addition further guidance regarding sentencing in general may be provided under other statutes such as those governing the procedure ${ }^{55}$ and the operations of particular level or type of court.

\subsubsection{Sentencing Aim $(s)$}

Under the existing sentencing regime there is no general aim or primary sentencing rationale with a statutory or similar force behind it to provide guidance and direction in sentencing. Generally speaking, with respect to most offences, it is left to the judge to determine the sentencing aim(s) for herself/ himself. There are at least three exceptions to this general rule. The first concerns situations where a mandatory minimum sentence is applicable. Often passed in response to a perceived escalation in particular crimes, mandatory minimum enactments usually have deterrence as their stated aim. The second exception is children's /juvenile justice, whose aims unlike those of the adult system are clearly stated. ${ }^{56}$ The third concerns those instances where, for public policy or other reasons, higher courts take it upon themselves to direct what the sentencing aim in respect of a particular offence or class of offenders shall henceforth be. In such cases the higher courts often state the sentencing aim(s) that must be at the back of the trial court's mind when dealing with such offences or offenders. For instance, they have indicated when it may be appropriate to impose sentences for reasons of deterrence, retribution and reform. ${ }^{57}$ The theme of deterrence is one that courts return to quite regularly. ${ }^{58}$ Higher courts have also pronounced on the general approach to custodial sentences where the persons concerned are first offenders. ${ }^{59}$

It should be evident from the foregoing that the system as a whole places great reliance upon appellate or supervisory review and guideline judgements of the higher courts to provide guidance to the sentencing courts. Appellate reviews offer general guidance and sometimes very specific directions regarding various aspects of sentencing, and that has the effect of channelling the thinking of judges

\footnotetext{
54) Criminal Procedure and Evidence Act.

55) See, e.g., Criminal Procedure and Evidence Act, Sections $298-315$.

56) See Children's Act, Section 28. In State v Molaudi and others (1989) BLR 24(CA) the Court of Appeal described the general spirit of the Children's Act, especially Section 28, as being non-punitive. More precisely, the court suggested that that section intended the treatment of juveniles to be remedial, protective and/or educational. See generally B. Maripe, 'The Recognition and Enforcement of Children's Rights in Domestic Law: An Assessment of Child Protection Laws in Light of Prevailing International Trends', 9 International Children's Rights Journal (2001), 339-355.

57) See, e.g., Masono v The State Criminal Appeal 35/99.

58) For, e.g., Mahomed v State 1984 BLR78 (CA).

59) State v Sethunya 1986 BLR $483(\mathrm{HC})$.
} 
in the desired direction, and may occasionally, restrict the discretion of judges in sentencing matters. But as a rule appellate courts are reluctant to interfere with sentences imposed by lower courts and generally allow the judges to find their own range. A number of judgments offer guidelines as to when the appellate courts will interfere with the sentence passed by the sentencing court.

For instance in the case of Mudangule $v$ State ${ }^{60}$ the court held that an appellate court will interfere with the sentence passed by the court below if it believes that the sentencing court misdirected itself or imposed a sentence which no reasonable trial court could have imposed. A more extensive list of circumstances that would warrant the interference of an appellate court with the decision of the trial court was provided in the earlier case of Mojagiv The State. ${ }^{61}$ In that case the Court of Appeal said interference with the sentence would be justified: ${ }^{62}$

\footnotetext{
(1) if the sentence is so manifestly excessive that a reasonable man would not have awarded it, taking into account the circumstances of the case; $(2)$ if there are circumstances appearing upon the record of the matter which have a bearing on the question of punishment but which the trial court failed to consider; (3) if the trial court followed the wrong principles in imposing the sentence; (4) if the trial court exceeded its jurisdiction in the matter of sentence, or (5) if the appellate court has before it fresh material which was not available to the trial court.
}

An appellate court may alter the sentence if it considers that it departs from the accepted range of punishment for the particular offence or is too low. ${ }^{63}$

In respect of the accepted range of punishment, speaking on behalf of the bench in Ntesang $v$ State ${ }^{64}$ regarding sentencing of certain types of murder, Lord Couldsfield said that 'any judge who has to deal with this kind of case would do well by thinking of a sentence in the region of 15 to 17 years, subject of course, to adjustments upwards or downwards, in light of any particular circumstances in the case before him'

\section{General Principles and Policies}

Apart from the circumstances described above, the sentencing discretion of judges must be exercised within certain parameters as defined by statutory law and common law principles relating to sentencing. These principles are too many to enumerate here save to note that the following may be counted amongst the most important: the proportionality principle, consideration of mitigating and aggravating factors, and taking into account and weighing against each other the

\footnotetext{
60) 1986 BLR 265 (CA) 265 .

61) 1985 B.L.R $560(\mathrm{HC})$.

62) Ibid., 561 .

63) See, e.g., Nthebolang $v$ State (1999) BLR 1(CA).

64) (2007) 1BLR 387, 391. See also Philaye v The State (2006) BLR 243 (CA) and Binikwa v The State Cr. App. CLCLB-034-08.
} 
well-known triad of factors that consists of the nature of the crime, circumstances of the offender and the interests of society when passing a sentence. ${ }^{65}$ The proportionality principle is integral to notions of justice and fairness as it requires that there should be some rough equivalence between the injury caused to society by the offender and the punishment he/she is liable to suffer in consequence. ${ }^{66}$ The principle is given express statutory recognition in Section 18(4) of the Customary Courts Act. ${ }^{67}$ In terms of that provision customary courts are prohibited from imposing on any person punishment 'which is not in proportion to the nature and circumstances of the offence and the circumstances of the offender. ${ }^{\prime} 8$ The proportionality principle also receives indirect recognition in the Constitution through Section $7(1)$ which prohibits the infliction of 'degrading, cruel and unusual punishment or other treatment.' Indeed, the Court of Appeal has confirmed in a number of judgements that punishment that is grossly disproportionate falls foul of Section $7(1)$ of the Constitution of Botswana. ${ }^{69}$

In deciding what the quantum of punishment should be, a court must take into consideration aggravating and mitigating factors. Alleged failure by the trial court to give sufficient consideration to mitigating factors is probably one of the most common reasons or grounds for appeal against sentence. Even though there is no law requiring the trial court to allow the offender or her/his legal representative the opportunity address the court in mitigation, the Court of Appeal has ruled that failure to do so is an irregularity. ${ }^{70}$ Such an irregularity may not be fatal if it does not result in the failure of justice but is nevertheless regarded in a serious light. In Hilda Ofetotse $v$ The State ${ }^{71}$ Bizos J.A., said in relation to mitigation

\footnotetext{
... Despite absence of any statutory provision entitling an accused to address the court in mitigation, there is a well-established rule of practice in the Courts of Botswana, South Africa and elsewhere whereby the defence is afforded the opportunity of tendering evidence in mitigation and making submissions to the Court before the sentence is passed. This practice is well known to all of us and we intend it to be followed.
}

On the other hand failure to give appropriate weight to aggravating factors which results in what the prosecution considers an unduly lenient sentence may trigger appeal by the state. On occasion it may result in enhancement of punishment by Court of Appeal, even where an appeal is brought by the convicted person himself/herself. Because of their importance in the sentencing process, it is essential to discuss aggravating and mitigating factors in some detail.

\footnotetext{
65) See, e.g., Kolagano v The State (1992) 49(HC) 51.

66) See N. Walker Why Punish? (Oxford University Press, Oxford, 1991), p. 101.

67) Customary Courts Act, Section 18(4).

68) Ibid.

69) See, e.g., Moatshe, supra note 2.

70) Court of Appeal, Criminal Appeal No 5/1989.

71) Ibid.
} 


\subsection{Aggravating and Mitigating Factors}

The range of factors that may be taken into account, especially mitigating factors, is potentially vast, and only a tiny percentage is mentioned in guideline judgments. It is therefore necessary to consider some form of rough classification in order to facilitate discussion. Following Ashworth ${ }^{72}$ it is considered that classification of aggravating and mitigating factors according to whether they are general to all offences or specific to particular offences is useful. Ashworth ${ }^{73}$ has usefully further broken mitigation down into the additional category of personal mitigation.

\subsubsection{Aggravating Factors}

\subsubsection{General Aggravating Factors}

Some general aggravating factors in Botswana include, amongst other factors premeditation and wickedness of the offender. In Puso $v$ The State ${ }^{74}$ which was an appeal by a youthful murderer against a death sentence for murder, Tebbut J.A speaking on behalf the bench of the Court of Appeal said:

The death sentence is, by virtue of the provisions of section 203 of the Penal Code, mandatory where a person of 18 years of age or older is convicted of murder without extenuating circumstances. It ought to be imposed on a teenager who has committed murder if it actually appears that he killed out of inherent wickedness.

\subsubsection{Specific Aggravating Factors}

There are two ways in which specific aggravating factors may be incorporated into an offence. The offence-creating statute may specify aggravating factors or provide for a separate offence incorporating an aggravating feature. In Botswana legislation tends to be crafted in such a way that sub-categories of the same general offence are treat as separate thus obviating the need to emphasize specific aggravating features, as is often the case where the offence categories are very broad. In this way the main offence categories are in effect gradations of the same general offence e.g. Assault Common, Assault Occasioning Bodily Harm, together with Grievous Bodily Harm belong to the same broad category. ${ }^{75}$ However each of these sub-categories may have some aggravating features specific to it.

\footnotetext{
72) Ashworth, supra note 9, 121-140.

73) Ibid., 129.

74) 1998 BLR 421(CA) 422 .

75) Each of these sub-categories may be fairly wide, as a result there may be some overlap between subcategories of the same broad offence. Because of this confusion may arise, therefore, as to the appropriate charge or sentence in a given instance. Appellate courts have sometimes found it necessary, where statutory meanings are vague or insufficiently distinct from parallel offences, to refine the meaning of such offences see, for example, State v Baiphethi (Practice Note) 1984BLR232(HC).
} 


\subsubsection{Mitigating Factors}

\subsubsection{General Mitigating Factors}

General mitigating factors are those factors that go to the seriousness of the offence. These may relate to harmfulness/potential harmfulness of the conduct for which the offender has been convicted, and her/his culpability. As regards the latter, Ashworth has quite rightly pointed out that some of the factors that are seen as reducing culpability are factors or circumstances that fall just short of a defence. ${ }^{76}$ In other words while they would fail as a defence in respect of the offence for which the offender has been convicted, they could work to the advantage of the offender if raised in mitigation.

\subsubsection{Specific Mitigating Factors}

Certain mitigating factors are specific to the offence concerned; for example, in murder cases the Penal Code provides that: 'in deciding whether or not there are any extenuating circumstances the court shall take into consideration the standards of behaviour of an ordinary person of the class of the community to which the convicted person belongs. ${ }^{77}$ Such considerations do not apply in respect of other offences.

\subsubsection{Personal Mitigating Factors}

These cover a range of factors which may also fall under general mitigation, e.g., youthfulness.

\subsection{Youthfulness ${ }^{78}$}

Courts in Botswana are anxious to give the young, especially where there appears to be a chance for reform, ${ }^{79}$ a second chance. In-school youth with prospects for further education may find that they often escape imprisonment for minor to moderately serious offences. If it is deemed necessary to send them to prison, part of the sentence may be suspended, and in serious cases reduced on account of their youthfulness. Immaturity and other factors associated with being young such as impulsivity are matters that a court must weigh when sentencing young persons. In Puso $v$ The State ${ }^{80}$ J.A. Tebbutt stated that:

\footnotetext{
76) Ashworth, supra note 9, 129.

77) Penal Code $\mathrm{s} 203(3)$

78) I am referring here to young persons who are 18 years of age and older.

79) In the case of State $v$ Baliki Charlie (High Court Review case No 140/1983 (unreported)) the then Chief Justice of Botswana O'Brien Quinn C.J. said that suspending a major part of a prison term and giving a young offender who appears likely to reform 'short, sharp, shock' by sending her/him only briefly to prison was the appropriate policy where young offenders were concerned if not sending them to prison could not be avoided.

80) 1998 BLR421 (CA) 427-428.
} 
Youthfulness is in itself regarded as an extenuating circumstance. In South Africa, ${ }^{81}$ where the law is the same as in Botswana, the Appellate Division of the Supreme Court has held that a teenager is prima facie regarded as immature and on that ground extenuating circumstances can be found unless it appears that there are factors which would negative such immaturity.

\subsection{First Offenders}

The general courts are slow to send first offenders to prison. However, a statement such as this must necessarily be qualified as the practice is not invariable. ${ }^{82} \mathrm{An}$ offender with prior convictions for a similar offence generally loses the sympathy of the courts in relation to that particular offence as it would appear that $\mathrm{s} / \mathrm{he}$ is incorrigible.

\subsection{The Guilty Plea}

The courts do not appear to take a firm view on what the effect of guilty plea on the sentence should be. ${ }^{83}$ But generally, if certain elements like a display of contrition are present, many judges would take the view that that should earn the offender a discount on her/his sentence.$^{84}$ However, it is misdirection for the sentencing court to punish an offender more harshly than it would otherwise do simply for pleading not guilty. ${ }^{85}$

(iv) Social Circumstances of the offender and Social Impact: the courts in Botswana do not, as a matter of general practice, call for a probation or social inquiry or pre-sentence reports when they are set to pass a sentence on an offender. However, the offender is free to call attention to his/her personal circumstances and how those around him/her might be affected by the sentence. Generally such matters as the employment status of the offender may very well influence the court's thinking if it appears that sending an offender to prison is likely not to benefit society or might have an excessively negative impact when all factors are taken into account. As regards other personal factors, however, the courts appear to have ruled out the accused person's ill health as mitigating factor 'save in exceptional cases or unless it has some relevance to the causation of the offence. ${ }^{86}$

\section{Emerging Trends and Reconfiguration of Judicial Discretion}

\subsection{Changing Attitude of the Legislature towards Judicial Discretion}

As noted in the opening section of this paper, there seems to have been a shift in the attitude of Botswana's legislature in the past two decades towards more

\footnotetext{
81) The judge was referring to a period in South Africa before the death penalty was abolished in 1995 .

82) The State v Sethunya $1986 \mathrm{BLR}_{4} 83(\mathrm{HC}) 483$.

83) See $S$ v Rahii 1981 BLR 252 (HC).

84) Ibid. See also State v Mavele Phili and Another High Court Review case No 355/1982 (Unreported).

85) See State v Phillimon 1983 BLR $30(\mathrm{HC})$.

86) State v Madumetse BLR 1981 195(HC) 195.
} 
deliberate efforts to alter sentencing patterns and practices through primary legislation. These efforts have involved a number of strategies such as increasing severity of penalties generally, ${ }^{87}$ and the enactment of mandatory minimum legislation. It seems that the former approach was used predominantly during the first two decades of independence while the latter came into greater use from the early 1990 on onwards. Two thirds of mandatory minimum enactments presently on the statute books were passed in last two decades and more specifically, the 1990s. Offences that have been affected by this shift towards mandatory minimum enactments include, inter alia, robbery, rape, defilement, drug-related offences, theft of motor vehicles and stock-theft.

This means that in recent times the legislature has been more willing to interfere directly with sentencing powers of judges and to deploy mandatory minimum legislation as a tool for fighting crime. As crimes like robbery and rape escalated, pressure for harsher penalties from general public and interest groups increased, parliament resorted to mandatory penalties in order to pacify them. Most of the dissatisfaction with extant penalties revolved around the perceived mildness of available penalties generally and the levels of punishment that the courts tended to impose for those offences. ${ }^{88}$

On the other hand, problems caused by mandatory minimum legislation have received very little public attention and media exposure despite the exponential increase in the volume of cases involving appeals to the Court of Appeal against sentence resulting from imposition mandatory penalties, over the past decade. The possible exception is the case of Baeta Ngwenya ${ }^{89}$ which received wide coverage in the media. The case involved a woman who was given a 10 year mandatory penalty for using force extract a very small amount of money from a friend. The sentence caused widespread dismay and concern.

Mandatory minimum provisions constrain judges in either one or both of two ways. First, they may require the imposition of a particular penalty for a given offence regardless of the circumstances of the case. This may result in a sentence that is 'grossly disproportionate to the offence' having regard to the circumstances of the case, or one that, in relation to the offence 'no-one could have possibly thought such an offence could possibly attract such a penalty', or one that is 'as excessive as to shock or outrage contemporary standards of decency. ${ }^{\prime 90}$ Second, where there is an obligatory requirement to impose a consecutive sentence where more than one count or offence is charged. This is a common feature of much of the mandatory minimum legislation promulgated in the 1990s. Not surprisingly, it

87) The latest example is the Road Traffic Amendment Act No 27 of 2008, the effect of which has been a shocking increase in quantum penalties for number road traffic offences.

88) See Nsereko, supra note $4,372$.

89) High Court Miscellaneous Application No. 47/97.

90) Motlhabane and Another $v$ S (CLBCB-107-09) (2010) BWCA27 per Lesetedi, para. 12. 
has been the subject of many appeals coming before the Court of Appeal in recent years because it tends to result in heavy aggregate sentences.

\subsection{Restoration of Discretion}

The provisions in the slew of mandatory minimum legislation passed by parliament from the early 199os onwards requiring courts to impose consecutive sentences added to the problem of inflexible sentences traditionally associated with mandatory penalties. As might be expected, such legislation has proved not to be popular with the judiciary because it represents further encroachment on their powers to deal satisfactorily and comprehensively with the permutations of cases coming before them. However, like the judiciary in other commonwealth jurisdictions they have accepted that sentencing policy, more specifically legislating how given offences should be punished remains the province of the legislature. ${ }^{91}$ But it would seem that in discharging that function parliament overreached itself especially in the 1990s in so far as the result of its efforts were in numerous instances found to be offensive to Section 7(1) of the Constitution by the Court of Appeal..$^{92}$ However, this should not be taken to imply that similar types of cases warranting this type of intervention did not occur prior to the 1990s. For instance, the Court of Appeal in the 1980s struck down a provision in the Habit Forming Drugs Act which required the imposition of a lengthy prison term coupled with corporal as punishment, as being in violation of Section $7(1)$ of the Constitution. ${ }^{93}$ In 2004 the legislature decided to amend the Penal Code after apparently realizing that some of the restrictions in mandatory minimum legislation caused serious problems for the courts. The amendment was intended, inter alia, to restore, to a limited extent, the discretion of judges. ${ }^{94}$ More specifically, the amendment was designed to allow the courts to impose a lesser, more suitable penalty 'if there are exceptional extenuating circumstances which would render the imposition of a statutory minimum penalty totally inappropriate. ${ }^{95}$

Following the decision in Moatshe, ${ }^{96}$ the Court of Appeal took a consistently robust approach to enactments, which in its view, constrained the discretion of a sentencing court such that it would not be able properly exercise its discretion to decide whether to order a sentence to run consecutively or consecutively as provided for under Section $300(2)$ of the Criminal Procedure and Evidence Act. ${ }^{97}$

\footnotetext{
91) Moatshe, supra note 2, 1.

92) Supra note 1.

93) Desai and Modiv The State (1985) B.L.R 582 (HC).

94) See K. Frimpong, supra note 13, 76.

95) Penal Code, Section 27(4).

96) Moatshe, supra note 2.

97) Criminal Procedure and Evidence Act, Section 300(2).
} 
In a series of judgements the Court of Appeal struck down such provisions in respect of stock theft, ${ }^{98}$ motor vehicle theft ${ }^{99}$ and rape. ${ }^{100}$

\section{Concluding Remarks}

The question whether the discretion of judges in relation to sentencing should, in principle, be subject to restrictions of whatever description especially through primary legislation remains very controversial. ${ }^{101}$ Judges in many countries are generally resolutely opposed to any attempts to restrict their discretion. Other groups of various descriptions, amongst them politicians have been as equality determined to see that judicial discretion in this area is brought under control.

Developments over the past two decades show that Botswana has gone almost full circle regarding judicial discretion in sentencing matters. It moved from a position of relative legislative abstinence before the 1990s, to one where, in relation to serious offences at least, the legislature imposed severe restrictions on judges through mandatory minimum enactments, and then back again towards the middle ground.

The shift towards restriction of sentencing discretion of judges in Botswana was consistent with both the wider movement in the common law world and the generally instrumentalist approach to criminal law in post-independence Africa. ${ }^{102}$ Like in other jurisdictions, the strongest objections from the judiciary have been registered whenever judges have been required to operate a mandatory minimum penalty regime in respect of some offence. Mandatory minimum legislation by definition imposes severe limitations on the powers of judges to decide cases according their own judgement, and in that regard it lies at the extreme end of the discretion continuum. Mandatory minimum penalties tend to increase the risk that there will be a violation of the principle that different cases should be treated differently ${ }^{103}$ because mandatory minimum legislation takes away the flexibility that judges require to take account of circumstances peculiar to each case. So in effect judges find themselves having to impose the mandatory sentence whatever the circumstances of the individual case.

Research from other jurisdictions suggests that where judges and prosecutors find mandatory minimum penalties particularly disagreeable, resistance

\footnotetext{
98) Section 3(5) of the Stock Theft Act struck down in Thabiwa, supra note 2.

99) Supra note 1.

100) Section 142(5) Penal Code in Ramphoi, supra note 2.

101) See, e.g., Ashworth, supra note 9; Tonry, supra note 9; Nsereko, supra note 4.

102) See Y. Ghai, 'The Role of Law in the Transition of Societies: The African Experience', 35 Journal of African Law (1991), 8-20. See also Turner and Coldham, supra note 11.

103) According to Tonry, supra note 9 , the equality of treatment principle has two tenets that must be satisfied to meet the requirement of justice, namely: to 'treat like cases alike' and to 'treat different cases differently'.
} 
may develop resulting in circumvention and non-compliance with mandatory sentences. ${ }^{104}$ While there is no evidence to suggest that there has been similar circumvention or non-compliance in Botswana, the judiciary has expressed its deep reservations regarding mandatory minimum penalties in a number of cases. ${ }^{105}$ The courts have systemically reclaimed some of the discretion they had lost. The move by Parliament to amend the Penal Code in 2004 suggests that parliament has in effect recognised and conceded that there is a need for more flexibility in the structure of sentencing discretion of judges. Thus, despite the unprecedented increase in the volume mandatory minimum legislation from the past two decades which still remains on the statute book, the sentencing of discretion judges has been partially restored by both the courts and the legislature.

More significantly, the general framework for the exercise of discretion in Botswana remains fundamentally unchanged despite the increase in the number of mandatory minimum enactments. Judges' discretion to decide most aspects of the sentence in respect of the overwhelming majority of offences, including the quantum of punishment, remains unaltered.

In sum, it is evident from the foregoing discussion that judges in Botswana have very wide discretion in sentencing matters save for a few areas where the legislature has for purposes of deterrence, introduced mandatory minimum sentences. For most common crimes the applicable regime allows the judge to decide on the appropriate sentence below a fixed maximum for that offence or offence category. As a rule the maxima is pitched very high. As already noted there is no general overarching sentencing aim to which judges may tailor their sentencing decisions. It is most often a matter for the judge to decide what he/she considers to be the appropriate sentencing aim. Judges also enjoy a lot of discretion in respect of other aspects of sentencing such as mitigation. There is very little guidance as to what factors may be considered and what weight they should be accorded. Lastly, appellate courts are generally reluctant to interfere with sentences passed by the lower courts purely for reasons of consistency. More substantial reasons than that must be present before they will interfere.

104) See generally M. Tonry, 'Structuring Sentencing', 10 Crime and Justice: A Review of Research (1988), 267-337.

105) See, in particular, Moatshe, supra (note 2). 